\title{
Inhalation anesthesia equipment for rats with provision of simultaneous anesthetic and oxygen ${ }^{1}$
}

\author{
Equipamento para anestesia inalatória em ratos com oferta simultânea de \\ anestésico e oxigênio
}

\begin{abstract}
Edinaldo Gonçalves de Miranda ${ }^{\text {, }}$ Vinícius Pontes do Nascimento ${ }^{\mathrm{II}}$, Daniel Reis Waisberg ${ }^{\mathrm{III}}$, Manoel Wilkley Gomes de Sousa ${ }^{\mathrm{IV}}$, Marcel Fernando Miranda Batista Lima ${ }^{\mathrm{IV}}$, Danilo dos Santos Silva ${ }^{\mathrm{IV}}$, Jaques WaisbergV

${ }^{1}$ Research performed at Department of Pediatric Surgery, Faculty of Medical Sciences, State University of Piaui (FACIME/UESPI) and Department of Surgery, Hospital do Servidor Publico Estadual, Sao Paulo-SP, Brazil.

${ }^{\mathrm{I}} \mathrm{MD}$, Assistant Professor, Head Division of Pediatric Surgery and Experimental Surgery, FACIME/UESPI, Piaui, Brazil. Responsible for conception and design of the study, analysis and interpretation of data, manuscript writing.

${ }^{\text {II }}$ MD, Volunteer, FACIME/UESPI, Piaui, Brazil. Helped with technical procedures, collection and processing of study informations.

III Graduate student, Faculty of Medicine, University of Sao Paulo (FMUSP), Brazil. Designed the protocol, technical procedures, statistical analysis and English language.

IV Graduate student, FACIME/UESPI, Piaui, Brazil. Involved with technical procedures, acquisition of data and manuscript writing.

${ }^{v}$ PhD, Associate Professor, Faculty of Medicine of ABC and Department of Surgery, Hospital do Servidor Publico Estadual, Sao Paulo-SP, Brazil. Intellectual and scientific content of the study, analysis and interpretation of data, critical revision.
\end{abstract}

\begin{abstract}
Purpose: To introduce a model of equipment for inhalation anesthesia in rats that offers better control of both flow and losses of ether during induction, maintenance, and recuperation. Methods: The equipment consists of an air compressor with two outlets, a closed glass induction chamber, a glass reservoir for the anesthetic agent, a pediatric inhalation mask, a three-way stopcock, a Y-connector, and urinary catheters. Three hundred Wistar rats (Rattus norvegicus albinus) were given inhalation anesthesia. The evaluated parameters were equipment operation, duration of each phase of anesthesia, corneal reflex, muscular tonus, respiration during induction and maintenance, and volume of anesthesia. Results: The average time taken for induction was 7.3 minutes; the average anesthetic recuperation time was 6.4 minutes. The amount of anesthetic used varied according to the weight of the animal, with the average volume of ether used being $6.5 \mathrm{ml} /$ hour. The availability of oxygen (room air) decreased the recuperation time and averted both respiratory depression and insufficient depth of anesthesia. Conclusion: The proposed equipment is practical, inexpensive, and allows for satisfactory control of anesthetic parameters during the entire procedure, making inhalation anesthesia in rats safe and essentially complication free.
\end{abstract}

Key words: Anesthesia. Anesthesia and Analgesia. Anesthesia, Inhalation. Ether, Ethyl. Rats.

\section{RESUMO}

Objetivo: Apresentar modelo de equipamento para anestesia inalatória em ratos, com melhor controle do fluxo, das perdas de anestésico na indução, da manutenção e da recuperação anestésica. Métodos: O equipamento é constituído por compressor de ar com saída dupla, câmara de vidro fechada para indução, reservatório de vidro para o agente anestésico, máscara de inalação pediátrica, torneira de três vias, conexão em "Y" e sondas uretrais. Trezentos ratos Wistar (Rattus norvegicus albinus) foram anestesiados por via inalatória. Os parâmetros avaliados foram: viabilidade do equipamento, tempo de cada fase, reflexo corneano, tônus muscular e movimentos respiratórios na indução e na manutenção anestésica, além do volume de anestésico. Resultados: A média do tempo gasto na indução anestésica foi de 7,3 minutos. A média do tempo de recuperação anestésica foi de 6,4 minutos. A média do volume de éter utilizado foi de $6,5 \mathrm{ml} / \mathrm{h}$. Não foram observadas neste experimento morte dos animais, aumento excessivo de secreção traqueobrônquica ou interrupção da operação por superficialização anestésica. Conclusão: O equipamento proposto é prático, possui baixo custo e permite o controle adequado dos parâmetros de controle da anestesia durante todo o procedimento, tornando a anestesia inalatória em ratos segura e praticamente isenta de complicações.

Descritores: Anestesia. Anestesia e Analgesia. Anestesia por Inalação. Éter Etílico. Ratos. 


\section{Introduction}

Rats are the most commonly used animals in experimental surgery. For these procedures, inhalation anesthesia is typically induced by a cotton-wool ball soaked in an inhalation agent (generally ethyl ether) that is placed within a closed chamber or box ${ }^{1,2}$. This same cotton ball is held near the animal's muzzle in order to maintain anesthesia during surgery ${ }^{3}$. This method has several disadvantages: the anesthetic escapes into the room air, respiratory depression often occurs due to difficulties controlling the volume of ether, induction is prolonged, and maintenance of a consistent anesthetic level is difficult because when the cotton ball is held against the animal's muzzle, upper airway resistance increases ${ }^{1}$. Brito et al. ${ }^{2,4}$ successfully developed equipment to reduce the impact of these issues.

The authors of the present study demonstrate modifications to the equipment that is described by Brito et al. ${ }^{2,4}$, with the additional advantages of oxygen availability and better control of the flow of the anesthetic agent with minimal loss to room air, making the equipment more useful and practical.

\section{Methods}

Following approval by the Ethics Committee for Animal Research of the Medical Sciences Faculty of Piaui (Brazil), 300 Wistar rats, without distinction of gender, weighing between $130 \mathrm{~g}$ and $230 \mathrm{~g}$, and aged between 100 days and 120 days (mean=108.3 days) were given inhalation anesthesia. The rats were kept at suitable temperatures and under ambient light, fed with nutrient-balanced feed and given free access to water.

The design of the anesthetic equipment can be described according to the following way: the air compressor with two outlets is connected to a Y-connector, as is a three-way stopcock. The stopcock is, in turn, connected to two \#12 urethral catheters - one for the conduction of air into the glass reservoir containing ether and protected by a rubber stopper, and the other connected to the inhalation mask. Two additional catheters exit the glass reservoir: the first and heaviest is a \#14 catheter for the flow of ether to the induction chamber, and the other is a \#12 that leads to the inhalation mask (Figures 1 and 2). Both of these catheters have a valve to control ether flow. All of the equipment and the four rubber straps were placed on top of a wooden table measuring $40 \mathrm{~cm}^{2}$.

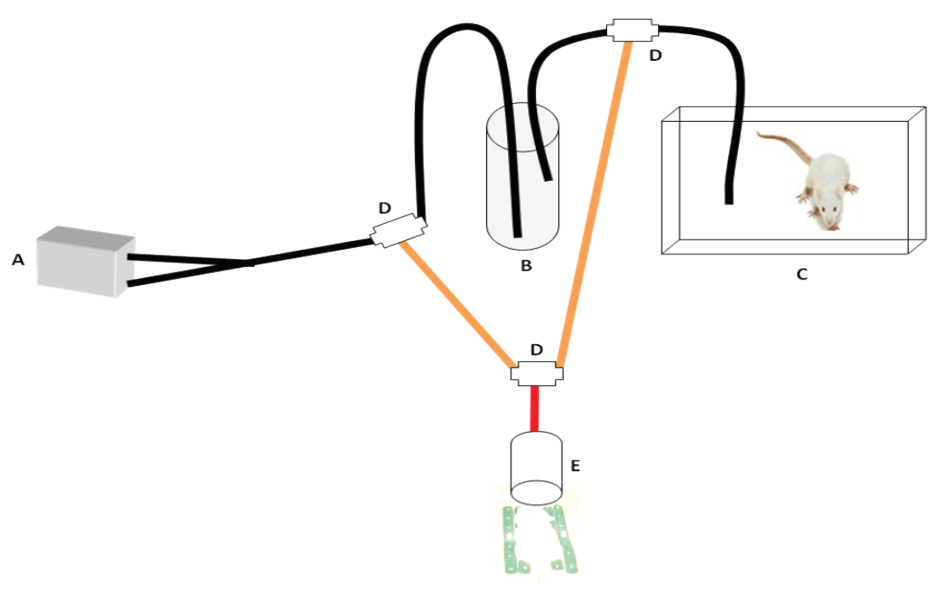

FIGURE 1 - Schematic design of the anesthesia equipment. A. Air compressor with two outlets (aquarium pump). B. Reservoir for inhalation agent. C. Inhalation chamber. D. Three-way stopcock for control of flow of anesthetic agent. E. Anesthetic mask for maintenance of anesthesia during the surgical procedure.

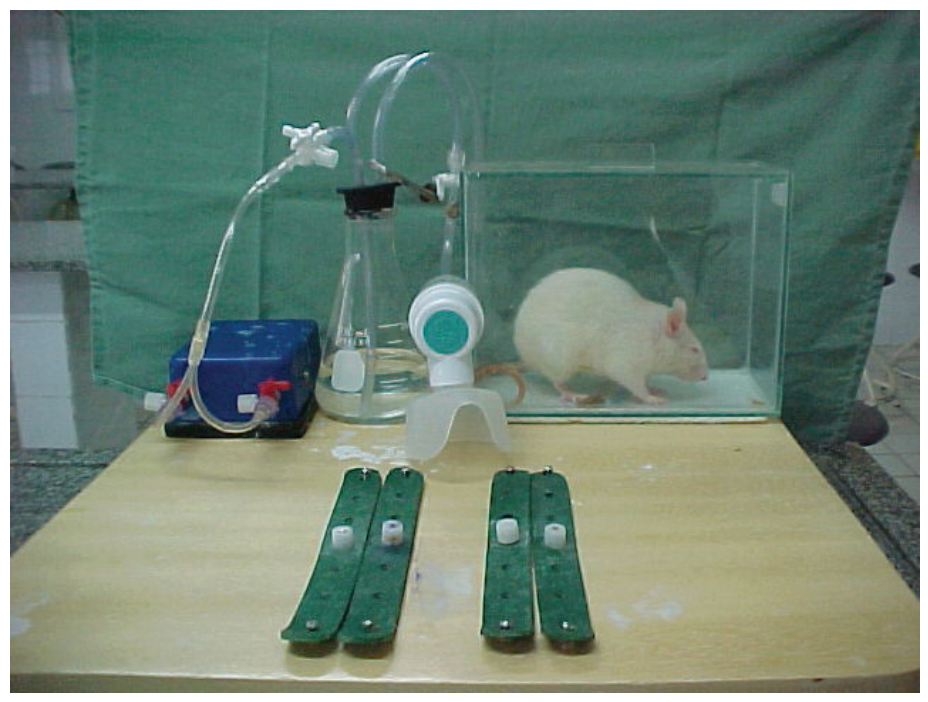

FIGURE 2 - Anesthetic equipment in use, with a rat in the induction chamber and the pediatric inhalation mask.

After induction, the animal was removed from the chamber and secured in the dorsal decubitus position using the rubber straps. Maintenance of the anesthetic plane was achieved using the pediatric inhalation mask, which could deliver ether, oxygen, or both (Figure 3). The control of ether and oxygen during the maintenance of and recovery from anesthetic was achieved by opening and closing the flow control valve, and was dependent upon the presence of insufficient anesthesia depth or, conversely, respiratory depression. 


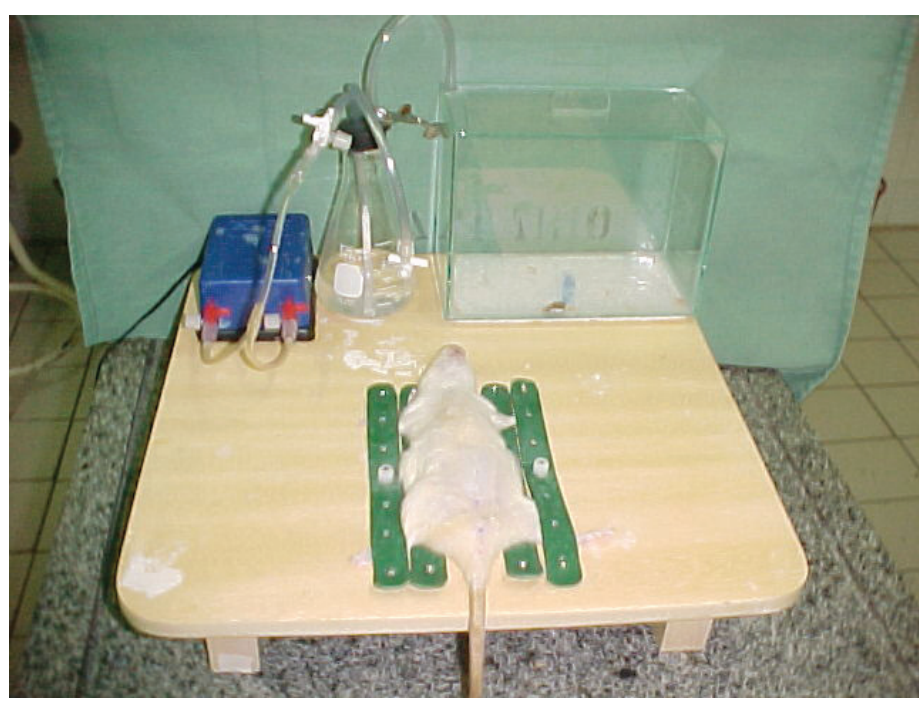

FIGURE 3 - Animal placed on the surgical table using rubber straps.

During induction, we monitored the following: corneal reflex, respiratory rate (RR) in respirations per minute (rpm), cardiac rate $(\mathrm{CR})$ in beats per minute $(\mathrm{bpm})$, degree of muscular tonus (MT), and minutes required for induction. During maintenance, the respiratory frequency and muscular tonus were observed. The recuperation time from anesthetic was taken as the time elapsed between the discontinuation of ether and the time the animal began walking unaided. The quantity of ether that was used in each stage of the procedure was also evaluated, as was the equipment's functionality and ease of use. The presence or absence of complications such as tracheobronchial secretions, lightening of the anesthesia plane, presence of respiratory depression, and death of the animal were noted throughout all phases of the procedure.

\section{Results}

The average time for induction was 7.3 minutes (range: 5-12 minutes), the average respiration rate was $94 \mathrm{rpm}$ (range: $80-120 \mathrm{rpm}$ ), and the average cardiac rate was $84 \mathrm{bpm}$ (range: 70 $90 \mathrm{bpm}$ ). Procedures took an average time of 55 minutes (range: 10-90 minutes) to complete with the continual use of ether. When the respiration rate fell below 100 per minute, or when an increase in the muscular tonus of the animal was observed, the ratio of oxygen to ether was altered such that the operation could continue without the suffering or death of the animal.

The amount of anesthetic used varied according to the animal's weight, with the average volume of ether used being $6.5 \mathrm{ml} /$ hour (range: $5-8 \mathrm{ml} / \mathrm{hr}$ ). The average anesthetic recuperation time was 6.4 minutes (range: 4-10 minutes), but the availability of oxygen (room air) reduced that time and prevented both respiratory depression and insufficient depth of anesthesia.

The equipment used in the present study was inexpensive and easy to use. It allowed for rapid induction, consistent anesthetic depth and recuperation, a low consumption level of ether with minimal resistance to flow, and adequate elimination of expired gases. No animal deaths occurred during this study and the level of tracheobronchial secretions was acceptable; in addition, there was no need to interrupt any of the operations due to insufficient anesthetic depth.

\section{Discussion}

Using the anesthetic equipment from this study, the air compressor generated a continuous flow to the anesthetic reservoir, producing bubbles of ethyl ether which were volatilized, and flowed through the catheters to both the induction chamber and the inhalation mask. The air flow produced by the compressor could also be sent directly to the inhalation mask without an anesthetic agent. The three-way stopcock determined the flow direction, while the regulatory valves controlled the amount of anesthetic that was delivered. The positioning of the animal was accomplished using graduated rubber elastic straps that were adjusted according to the size of the rat.

Notwithstanding the great improvements made by Brito et $a l^{2,4}$ in anesthetic equipment models for rats, the construction of this anesthetic equipment came from a need to resolve persistent problems with inhalation anesthesia ${ }^{5}$. This new method retains such advantages of Brito's model ${ }^{2,4}$ as low cost, ease of use, acceptable level of tracheobronchial secretions during induction, a small amount of anesthetic agent used and lost to the environment ${ }^{5}$.

Additionally, this new equipment offers the following advantages: (1) the valve system allows for better control of the anesthetic flow by permitting observation of the type of bubbles (small, medium or large) that are produced during volatilization of the ether ${ }^{4,6} ;(2)$ fewer complications arise from respiration resistance and the accumulation of expired gases since the ether-soaked cotton ball placed next to the animal's muzzle is replaced by the inhalation mask; (3) the availability of isolated or simultaneous oxygen, which allows for the elimination of expired air under the inhalation mask and prevents re-inhalation of expired gases; and (4) the ability to regulate the anesthetic concentration of the inhalation mixture, which minimizes problems such as respiratory depression, insufficient depth of anesthesia, and prolonged recovery from anesthesia. The fact that the equipment is coupled to a suitable surgical table, with straps to immobilize the animal, further increases its ease of use and efficiency. Overall, the equipment is reliable, and no complications are related to its use. Vivas et al. ${ }^{7}$ published an original model for inhalation anaesthetic equipment in small animals getting excellent results with the use of anaesthetic halothane and sevoflurane, currently used at Piaui State University under the Ethics Committee's recommendation to abandon the use of ethyl ether.

The only disadvantage identified by the authors was that the connections, valves, and plastic catheters became worn with repeated use and had to be replaced after 120-180 hours. This time period depends chiefly upon the ratio of oxygen to ether used; however, these materials are inexpensive, and also could be replaced by glass or metal connections that have a longer lifespan. 


\section{Conclusion}

The proposed equipment is practical, inexpensive, and allows for satisfactory control of anesthetic parameters during the entire procedure, making inhalation anesthesia in rats safe and essentially complication free.

\section{References}

1. Lee DK, Terrazas RG, Votto LG, Arenson-Pardikow H. Técnica de indução inalatória em ratos: estudo comparativo. Acta Cir Bras. 1994;9(1);34-7.

2. Brito MHV, Brito NMB, Almeida AJB, Santos MRLC. Vaporizador artesanal de éter para cirurgia experimental em pequenos roedores. Acta Cir Bras. 1998;13(1):3-7.
3. Sullivan J, Romm J, Reilly M. A brief report of student research: mechanism of analgesic effect and efficacy and anesthesia interactions of kava in the male Sprague-Dawley rat. Dimens Crit Care Nurs. 2009;28(3):138-40.

4. Brito MVH. Modificação do vaporizador artesanal de éter para cirurgia experimental. Rev Bras Anestesiol. 1999;49(2):107-9.

5. Fonseca NM, Goldenberg S. Sistema circular de anestesia para animais de pequeno porte: estudo das resistências ao fluxo de ar. Rev Bras Anestesiol. 1993;43(5):303-11.

6. Sousa F, Paes AMA, Alves HFP, Sirote FJ, Mathias PCF. Vaporizador de éter para cirurgia experimental em ratos. Acta Cir Bras. 1997;12(4):270-2.

7. Vivas LAM, Jamel N, Refinetti RA, Silva LF, Rodrigues LV, Silva PC, Schanaider A. Anesthetic experimental device for small animal. Acta Cir Bras. 2007;22(3):229-33.

Conflict of interest: none

Financial source: none

\section{Correspondence:}

Edinaldo Gonçalves de Miranda

Rua Jaime da Botica, 3442

64052-200 Teresina - PI Brasil

Phone: (55 86)9982-2987

edinaldomiranda@hotmail.com

Received: September 23, 2010

Review: November 18, 2010

Accepted: December 21, 2010 